\title{
The Southern Ocean Iron RElease Experiment (SOIREE)- introduction and summary
}

\author{
P.W. Boyd ${ }^{\mathrm{a}, *}$, C.S. Law ${ }^{\mathrm{b}}$ \\ ${ }^{\mathrm{a}}$ National Institute of Water and Atmospheric Research (NIWA), Centre for Chemical and Physical Oceanography, \\ Department of Chemistry, University of Otago, Dunedin, New Zealand \\ blymouth Marine Laboratory, Prospect Place, The Hoe, Plymouth, Devon PL1 3DH, UK
}

\begin{abstract}
This volume is dedicated to the Southern Ocean Iron RElease Experiment (SOIREE), the first in situ iron fertilisation experiment performed in the polar waters of the Southern Ocean. SOIREE was an interdisciplinary study involving participants from six countries, and took place in February 1999 south of the Polar Front in the Australasian-Pacific sector of the Southern Ocean. Approximately $3800 \mathrm{~kg}$ of acidified $\mathrm{FeSO}_{4} \cdot 7 \mathrm{H}_{2} \mathrm{O}$ and $165 \mathrm{~g}$ of the tracer sulphur hexafluoride $\left(\mathrm{SF}_{6}\right)$ were added to a $65-\mathrm{m}$ deep surface mixed layer over an area of $\sim 50 \mathrm{~km}^{2}$. Initially, mean dissolved iron concentrations were $\sim 2.7 \mathrm{nM}$, but decreased to ambient levels within days, requiring subsequent additions of $1550-1750 \mathrm{~kg}$ of acidified $\mathrm{FeSO}_{4} .7 \mathrm{H}_{2} \mathrm{O}$ on days 3,5 and 7 of the experiment. During the 13-day site occupation there were iron-mediated increases in phytoplankton growth rates, with marked increases in chlorophyll $a$ (up to $2 \mu \mathrm{g} 1^{-1}$ ) and production rates (up to $\left.1.3 \mathrm{~g} \mathrm{C} \mathrm{m}^{-2} \mathrm{~d}^{-1}\right)$. These resulted in subsequent changes in the pelagic ecosystem structure, and in the cycling of carbon, silica and sulphur, such as a $10 \%$ drawdown of surface $\mathrm{CO}_{2}$. The SOIREE bloom persisted for $>40$ days following our departure from the site, as observed via SeaWiFS remotely sensed observations of Ocean Colour. Papers in this volume report in detail on aspects of this study, from the oceanographic setting of the experiment to a modelling simulation of the SOIREE bloom. A CD-ROM accompanies this volume and contains the main SOIREE datasets and ancillary information including the pre-experiment 'desktop' database study for site-selection, and satellite images of the SOIREE bloom. (C) 2001 Elsevier Science Ltd. All rights reserved.
\end{abstract}

* Corresponding author. Tel.: + 64-3-479-5249; fax: + 64-3-479-5248.

E-mail address: pboyd@alkali.otago.ac.nz (P.W. Boyd). 


\section{Introduction}

One of the guiding principals upon which our understanding of marine biogeochemistry is based is the correlation between macronutrient availability and phytoplankton production. However, observations in the open-ocean waters of the Southern Ocean as early as the 1920s pointed to the presence of high nutrients, yet low phytoplankton biomass (Gran, 1931; see review in de Baar, 1994). These apparently irreconcilable trends were referred to as the Antarctic paradox, for which Gran suggested that "the growth of the plankton diatoms is determined by other factors than the concentration of phosphates and nitrates besides light and temperature". During the Discovery expedition to the Southern Ocean, Hart (1934) hypothesized that the greater abundance of diatoms in neritic waters (compared to offshore waters) may be attributable to coastal sources of trace elements or organics (see review in de Baar, 1994).

No significant insights into the Antarctic paradox were made until the late 1980s when, with improved analytical techniques, Martin et al. (1990) confirmed low dissolved iron levels (subnanomolar) and their potential role in determining phytoplankton processes in the open Southern Ocean. These observations were supported by concurrent research in polar waters by de Baar et al. (1989), which suggested that iron supply might control the magnitude of algal stocks. Over the following decade there was considerable debate as to the factor(s) that limit phytoplankton stocks in the three High Nitrate Low Chlorophyll (HNLC) regions, the open Southern Ocean, the equatorial, and subarctic Pacific (see Banse, 1990; Martin et al., 1991). Limitation of algal stocks by light availability (Mitchell et al., 1991) and grazing (Banse, 1990) were also considered, but iron availability was given added significance by the emergence of the Iron Hypothesis (Martin, 1990). This proposed a link between iron supply, phytoplankton production, and the sequestration of carbon to depth during the last glacial maximum, which was responsible for mediating atmospheric $\mathrm{CO}_{2}$ levels.

Two differing approaches, deckboard iron enrichments (see review in de Baar and Boyd, 1999) and oceanographic surveys of dissolved iron concentrations and phytoplankton stocks (de Baar et al., 1995), were adopted to examine the relationship between iron supply and phytoplankton growth in the Southern Ocean. The former studies were controversial in that they did not mimic conditions in the open ocean (such as sinking, advection) and there were uncertainties over the exclusion of grazers (Banse, 1991). The latter approach provided circumstantial evidence of an iron-limited phytoplankton growth based on the observed correlation between iron concentrations in the surface ocean and chlorophyll $a$ levels. Although both approaches provided strong evidence of the role of iron, they could not completely exclude other factors. The limitations of these approaches were overcome by mesoscale iron enrichment of HNLC waters in the equatorial Pacific, with tracking of the fertilised waters using a conservative tracer sulphur hexafluoride (Watson et al., 1991; Martin et al., 1994; Law et al., 1998). The subsequent IronEx II, unequivocally demonstrated that iron supply controls phytoplankton processes and subsequently influences carbon and sulphur biogeochemistry in the HNLC equatorial Pacific (Coale et al., 1996). However, this region is not considered as a significant area for iron-mediated carbon sequestration, whereas the HNLC waters of the Southern Ocean may be more important as a result of the intermediate and deep water formation in this region (Sarmiento and Orr, 1991; Cooper et al., 1996).

In light of the findings of IronEx II, a mesoscale iron enrichment in the polar waters of the Southern Ocean was the next logical step (Frost, 1996), although it was acknowledged that such an 
experiment would be logistically difficult (Coale et al., 1996) and potentially complicated by other factors. Research after IronEx II had indicated that phytoplankton in the Southern Ocean might be limited by both iron and light (Sunda and Huntsman, 1997; Boyd et al., 1999). Furthermore, silicic acid availability in these waters, particularly during summer, may also limit phytoplankton growth (Boyd et al., 1999). Also, little was known about the secondary effects upon other trophic levels, such as the response of grazers (Banse, 1991) to iron-elevated phytoplankton stocks.

The study of the response of biogeochemical cycling in the surface mixed layer to iron enrichment was limited within deckboard studies. Modelling simulations of the influence of iron enrichment in the Southern Ocean on atmospheric $\mathrm{CO}_{2}$ levels (Peng and Broecker, 1991) have yet to be verified and validated. In the absence of data, such models assume that iron enrichment results in complete utilisation of upper ocean macronutrients. Yet up to six-fold differences have been reported in chlorophyll $a$ levels and concomitant macronutrient uptake between deckboard iron enrichments (see review in de Baar and Boyd, 1999) and in situ observations in the open Southern Ocean (Comiso et al., 1993; Moore et al., 1999). These issues could only be addressed by conducting an in situ iron fertilisation experiment in open Southern Ocean waters to assess what controls the magnitude of phytoplankton stocks.

\section{The SOIREE site}

Site selection was critical to the outcome, interpretation, and extrapolation of the SOIREE. The site needed to meet several criteria: be representative of a broad region of circumpolar HNLC waters, yet have sufficiently low current shear to maximise the timescale that the fertilised patch could be tracked. In addition, the depth of the surface mixed layer at the site should be regionally representative, but not so deep that the resident cells would be iron/light co-limited (Sunda and Huntsman, 1997) or the added iron/sulphur hexafluoride $\left(\mathrm{SF}_{6}\right)$ would be overly diluted in the turbulent surface layer. The site selection for the SOIREE was accomplished by a 'desktop' database study using climatological datasets from the Southern Ocean (such as bathymetry, seasonal amplitude of Sea Surface Temperature, mean mixed-layer depth, wind speed, buoy drift trajectories), which are presented on the accompanying CD-ROM. This volume is opened by Trull et al. (2001), who describe the physical setting for SOIREE (Fig. 1), placing the locale in the context of comprehensive World Ocean Circulation Experiment (WOCE) physical and chemical oceanographic datasets for this region, and providing a detailed rationale for the site selection. Datasets from previous years presented by Trull et al. indicate that the initial biological and chemical conditions observed at the SOIREE site were typical of those at the end of the algal growth season in these waters. Moreover, the quiescent nature of this region - that made it an appropriate site for the experiment - is evidenced from a WOCE time-series of geostrophic current velocities, which indicate that the geographical location of the main frontal features in this region remain relatively constant on each of six WOCE surveys.

The detailed database survey provided us with secondary site selection criteria - such as the mean mixed-layer depth for summer - that were adopted for the survey upstream (to the west) of the potential release site (see Fig. 1). Results from CTD and XBT's displayed a mixed-layer, underpinned by a sharp pycnocline, with depths $\sim 65 \mathrm{~m}$ as suggested by the desktop survey (Boyd et al., 2000). Mixed-layer nitrate and phosphate concentrations (Table 1) were relatively high, silicic 


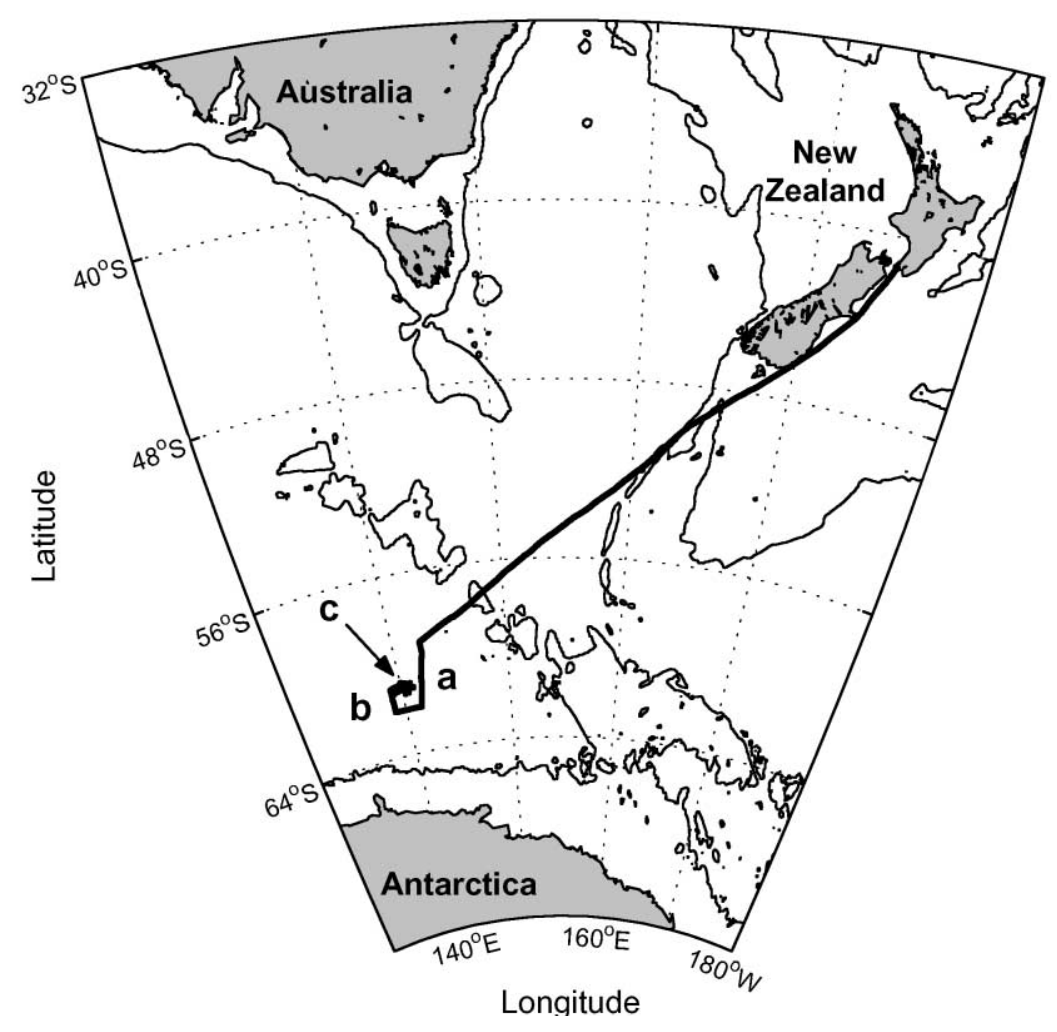

Fig. 1. The vessel track during the SOIREE voyage showing the location of, (a) a north-south CTD survey (along part of a repeat Hobart to Dumont-Durville hydrographic transect conducted regularly by the vessel Astrolab) to confirm the geographical location of the major frontal features: these had been ascertained during XBT surveys 30 and 14 days prior to the SOIREE voyage by the vessel Astrolab; (b) the pre-release survey upstream (west) of the likely SOIREE site; and (c) the site for the experiment.

acid concentrations intermediate (see Zentara and Kamykowski, 1981), and dissolved iron levels were relatively low for polar waters (see de Baar et al., 1999). The phytoplankton community exhibited sub-optimal values of photosynthetic competence $\left(F_{\mathrm{v}} / F_{\mathrm{m}}\right.$, see Table 1$)$ and was thus resource-limited, and based on the flavodoxin assay the resident diatoms were iron-stressed (Boyd et al., 2000). Thus, we had conditions that were both broadly representative of polar open waters in summer, and which provided favourable conditions for the initiation and maintenance of an iron-enriched patch. Furthermore, the region was characterised by low and homogeneous chlorophyll $a$ levels (see SeaWiFS images on the CD-ROM) from which to distinguish any iron-mediated algal response.

\section{The experiment}

The SOIREE took place between 9 and 22 February 1999 at $61^{\circ} \mathrm{S} 140^{\circ} \mathrm{E}$ (Fig. 1). Iron was added along with the chemically inert tracer $\mathrm{SF}_{6}$ at the start of the experiment. There were subsequent iron additions on days 3, 5 and 7 of SOIREE (see Table 2, this study; Boyd et al., 2000). The release 
Table 1

Summary of the initial conditions at the SOIREE site $\left(61^{\circ} \mathrm{S} 140^{\circ} \mathrm{E}\right)$. Error estimates represent 1 standard error of the mean

\section{Property}

\section{Temperature $\left({ }^{\circ} \mathrm{C}\right)$}

Density $\left(\mathrm{kg} \mathrm{m}^{-3}\right)$

Mixed-layer depth (m)

Chlorophyll $a\left(\mu \mathrm{gl}^{-1}\right)$

Nitrate $(\mu \mathrm{M})$

Silicate $(\mu \mathrm{M})$

Phosphate $(\mu \mathrm{M})$

Dissolved iron (nM)

Iron-binding ligands $(\mathrm{nM})^{\mathrm{a}}$

Algal community structure

$F_{\mathrm{v}} / F_{\mathrm{m}}$

Diatom iron stress (flavodoxin)

Euphotic zone depth $\left(\mathrm{m}, 1 \% I_{\mathrm{o}}\right)$

Community primary production $\left(0-65 \mathrm{~m}, \mathrm{mg} \mathrm{C} \mathrm{m}^{-2} \mathrm{~d}^{-1}\right)$

Mesozooplankton stocks $\left(0-70 \mathrm{~m}, \mathrm{~g} \mathrm{C} \mathrm{m}^{-2}\right)$

Heterotrophic bacterial abundance $\left(\times 10^{8}\right.$ cells $\left.1^{-1}\right)$

$$
\begin{aligned}
& 2.0 \pm 0.05 \\
& 27.0 \pm 0.05 \\
& 65.0 \pm 2.0 \\
& 0.25 \pm 0.03 \\
& 25.0 \pm 1 \\
& 10.0 \pm 0.4 \\
& 1.5 \pm 0.2 \\
& 0.08 \pm 0.03 \\
& 3.8 \pm 0.4 \\
& \text { Picophytoplankton-dominated } \\
& 0.22 \pm 0.02 \\
& \text { High } \\
& 84.0 \\
& 120.0 \pm 17.0 \\
& 1.6 \pm 0.86 \\
& 3.0 \pm 0.1
\end{aligned}
$$

\begin{tabular}{|c|c|c|c|c|}
\hline \multicolumn{5}{|c|}{$\begin{array}{l}\text { Table } 2 \\
\text { Summary of the addition of the tracer sulphur hexafluoride }\left(\mathrm{SF}_{6}\right) \text { and iron to the upper ocean at the SOIREE site. The } \\
\text { iron was added as acidified } \mathrm{FeSO}_{4} \cdot 7 \mathrm{H}_{2} \mathrm{O} \text { concurrently with } \mathrm{SF}_{6} \text { to a patch of } \sim 50 \mathrm{~km}^{2} \text { on Day } 0(9 \mathrm{February} 1999) \text {. } \\
\text { Subsequent re-infusions at the patch centre took place on days } 3,5 \text { and } 7 \text {, over areas of } 32,33.8 \text { and } 38.5 \mathrm{~km}^{2} \text {, respectively. } \\
\text { No further additions of } \mathrm{SF}_{6} \text { were required. Just prior to SOIREE, the solutions were mixed using a dosing unit to control } \\
\text { the pumping rate of iron and } \mathrm{SF}_{6} \text { into surface waters (at } \sim 15 \mathrm{~m} \text { depth using a depressor) }\end{array}$} \\
\hline Property & Infusion \# & Date /day & Addition & Enrichment \\
\hline $\mathrm{F}_{6}$ & 1 & 9 February/ Day 0 & $165 \mathrm{~g}$ in 36001 seawater & $300 \mathrm{fM}$ \\
\hline ron & 1 & Day 0 & $3813 \mathrm{~kg}$ in 28,0001 & $3.8 \mathrm{nM}$ \\
\hline ron & 2 & Day 3 & $1550 \mathrm{~kg}$ in 12,0001 & $2.6 \mathrm{nM}$ \\
\hline ron & 3 & Day 5 & $1550 \mathrm{~kg}$ in 12,0001 & $2.6 \mathrm{nM}$ \\
\hline ron & 4 & Day 7 & $1750 \mathrm{~kg}$ in 80001 & $2.5 \mathrm{nM}$ \\
\hline
\end{tabular}

was co-ordinated within a Lagrangian framework to account for surface water advection (Law et al., 1998). During SOIREE, the centre-point of the patch was marked using a WOCE-type surface drifting buoy attached to a holey-sock drogue centred at $30 \mathrm{~m}$ depth and fitted with GPS and ARGOS. The buoy position was updated every 10 min by UHF link. The release track was based upon an expanding hexagon around the centre-point with track spacings at $600 \mathrm{~m}$ intervals and a ship speed of 2-3 knots. 
In this volume, Frew et al. (2001) report on the distributions of macro-nutrient and trace-metals within and outside the fertilised patch during the bloom evolution. The authors also use macronutrient uptake stoichiometry and macronutrient: trace element ratios to predict conditions prior to the experiment, when the estimated seasonal removal of silicic acid and nitrate were indicative of an iron-limited algal population. During the SOIREE bloom they reported that the removal of silicic acid and nitrate over the 13 days was close to unity-i.e. the $\mathrm{Si}$ : $\mathrm{N}$ uptake ratio had halved as reported by Takeda (1998) for laboratory cultures of polar diatoms. Moreover, they saw no evidence of marked decreases in zinc concentrations that might result in the limitation/colimitation of algal growth by other trace elements. Frew et al. observed that cadmium was partitioned between dissolved and particulate phases in a manner implying a large fractionation with respect to phosphate $(a>5)$, and they comment on the implications of this observation for the interpretation of paleoceanographic records.

Croot et al. (2001) report on temporal trends in the concentrations of iron-binding ligands during SOIREE, where they observed marked increases in ligand concentrations towards the end of the experiment. They examine the mechanisms that could have supported the maintenance of high dissolved-iron levels via the persistence of high $\mathrm{Fe}^{\mathrm{II}}$ concentrations, which was recorded by day 12/13 of SOIREE, but has not been reported in other studies of upper-ocean iron cycling. They suggest that these ligands play an important role in controlling iron speciation, and may have contributed to the maintenance of the observed high $\mathrm{Fe}^{\mathrm{II}}$ concentrations.

The response of the phytoplankton community to iron enrichment is explored in several manuscripts. Gall et al. (2001a) describe iron-mediated changes in phytoplankton physiology and community structure observed in the water column. Several of the trends they observed-decreased C: chla ratios, a floristic shift from small (pico-eukaryotes) to large cells (chain-forming diatoms), and an increase in algal cell size — also have been reported during the IronEx II study in eastern equatorial Pacific waters (Cavender-Bares et al., 1999; Landry et al., 2000). In an accompanying paper (Gall et al., 2001b) report temporal trends in rates of primary and biogenic silica production during the study. Marked increases in the latter did not occur until day 6/7, coinciding with the floristic shift to diatoms in the fertilised waters. They indicate that the $\mathrm{Si}: \mathrm{C}$ uptake rate was halved upon iron addition, in accordance with the observations of Frew et al. (2001). Gall et al. (2001b) also present the findings of two deckboard perturbation experiments investigating ironlight, and iron/silicic acid/zinc co-limitation. The former experiment pointed to the importance of mixed-layer depth at any proposed site for such an in situ iron-enrichment experiment in the Southern Ocean, while the latter indicated no such trace element or nutrient co-limitation during the 13 day site occupation.

Changes in the photosynthetic properties of the phytoplankton community during SOIREE are investigated and discussed by Boyd and Abraham (2001). In contrast to the IronEx II study, they observed a more gradual increase in algal photosynthetic competence ( 7 days to double $F_{\mathrm{v}} / F_{\mathrm{m}}$ compared with $24 \mathrm{~h}$ in IronEx II), which they attribute to the polar water temperatures and relatively deep mixed layers. It was also apparent from their study that the photosynthetic competence of all algal size classes increased upon iron enrichment, and thus the observed diatom-dominated SOIREE bloom was the result of both iron supply and low rates of herbivory on these large cells. Indeed iron availability and relatively low mesozooplankton grazing activity appear to have continued, as Abraham et al. (2000) report on the exceptional longevity ( $>40$ days) of the SOIREE bloom as evidenced from SeaWiFS satellite images of the study region. Maldonado 
et al. (2001), in a detailed study of the responses of phytoplankton physiological properties (such as iron uptake kinetics) to observed shifts in iron chemistry in the SOIREE waters, provide a mechanistic explanation for this longevity. They suggest that the phytoplankton cells adjusted their capacity to take up iron at moderate (i.e. less than maximal) rates in response to changes in iron speciation on Days 11-12 of the SOIREE, which may, paradoxically, have led to the persistence of the bloom.

The subsequent influence of iron-elevated phytoplankton production and floristic shifts on the microbial foodweb is presented by Hall and Safi (2001). Based on the timing of increases in the rate of bacterial production (after day 7), they suggest that heterotrophic bacteria were not iron-limited at this site, but instead may have been limited by the availability of Dissolved Organic Carbon (DOC) and/or Nitrogen (DON). The microzooplankton community during SOIREE was dominated by nanoflagellates rather than the larger ciliates and/or tintinnids, which are reported to be the main components of the microzooplankton in other oceanic regions. This dominance by heterotrophic nanoflagellates may have permitted autotrophic nanoplankton stocks to increase to relatively high levels until day 10 (when heterotrophic ciliate stocks increased): these haptophytes were probably important in the production of DMSPp (dimethylsulphoniopropionate; the algal precursor of dimethyl sulphide (DMS)). In contrast to these shifts in the microbial foodweb, the response of the higher trophic levels to changes in both the microbial and algal community structure were less pronounced (Zeldis, 2001). Zeldis explored the dynamics of the mesozooplankton community during SOIREE and observed low rates of herbivory both within and outside the iron-fertilised waters.

In previous in situ mesoscale iron fertilisations, such as IronEx II, limited information was obtained on the fate of the accumulated algal carbon via export (see Bidigare et al., 1999). During SOIREE, studies investigated both the characteristics of particles in the upper ocean, and compared the downward fluxes of biogenic particulates from the SOIREE bloom with those in the surrounding HNLC waters. The characteristics and evolution of the biological particle populations during SOIREE are presented by Waite and Nodder (2001), who observed a shift in the size spectra towards larger particles during the bloom evolution, in contrast to outside waters. They were also able to compare the composition of particles within the mixed layer, relative to those intercepted by drifting traps at depth: large diatom-rich aggregates of up to several centimetres were intercepted by the traps. In addition, Trull and Armand (2001) report on changes in the carbon stable isotopic signatures of different particle size fractions, and present evidence of a strong relationship between isotopic signature and algal size. The first measurements of downward particulate fluxes of carbon, nitrogen and opal, as intercepted by free-drifting surface-tethered sediment traps, in a mesoscale in situ iron release experiment are described by Nodder and Waite (2001). Although differences in biogenic fluxes were observed between the iron-fertilised waters and the surrounding HNLC waters, there was sufficient variability in the fluxes in each 'water mass' to confound interpretation of these data (see below).

In addition to this volume, other SOIREE studies investigated aspects of the dispersal and mixing of the $\mathrm{SF}_{6}$-labelled waters. Law et al. (in preparation) estimate the vertical diffusivity at the base of the mixed layer from the diapycnal transfer of the tracer during the SOIREE, and apply this to estimate the supply of nutrients from sub-pycnocline waters. Abraham (in preparation) further examines the lateral dispersion and evolution of the tracer patch and the processes determining its transport. Additional iron-mediated impacts on the biogeochemistry of the surface waters are 
described in studies that examine the distributions and changes in the concentrations of climatereactive gases. Bakker et al. (2001) quantify the drawdown of carbon dioxide in the iron-enriched patch and estimate net and gross total dissolved inorganic carbon uptake. Their observations support those of others from SOIREE (Boyd and Abraham, 2001) and IronEx I (Watson et al., 1994) of a threshold concentration - of dissolved iron - for the limitation of phytoplankton growth. The results of Law and Ling (2001) indicate an increase in production of the greenhouse gas, nitrous oxide, in the pycnocline of the iron-enriched patch; and they examine the potential mechanisms for this observation. Their observations of a short-term response and calculations of the long-term response of nitrous oxide production in the ocean suggest that atmospheric nitrous oxide flux may increase in response to iron fertilisation. The influence of iron-enrichment on the sulphur cycle is detailed by Turner et al. (2001), who observed marked biologically-mediated shifts in DMSPp and DMS concentrations during the bloom. The longer response time of DMS and DMSPp production in SOIREE (compared with IronEx II) was attributed to both slower physiological responses and trophic interactions in the Southern Ocean. As a result, DMS concentrations were highest at the end of the SOIREE, and Turner et al. discuss their potential impact upon atmospheric albedo.

\subsection{Budgets and modeling}

The findings of SOIREE are summarised in budgetary and modeling studies. Bowie et al. (2001) constructed a detailed iron budget for SOIREE, which provides insights into the cycling and fate of iron during the experiment. They report on the major loss terms for the added iron in $\mathrm{SF}_{6}$-labeled waters, indicating that the dilution of the patch and abiotic particle scavenging were the main losses. Significantly, their budget suggests that the recycling of iron through the grazer community is able to support a significant proportion of the algal iron requirements of the SOIREE bloom, indicative of a self-sustaining system. Hannon et al. (2001) employed the recent SWAMCO model (Lancelot et al., 2000) to simulate the SOIREE bloom evolution. In general, they were able to reproduce the timing and magnitude of many of the bloom signals - such as that for algal biomass, primary production rates, and the drawdown of $\mathrm{CO}_{2}$. In the absence of observations between the end of the 13-day site occupation and the remotely sensed observations on day 42, the model runs yield insights into the bloom evolution and status during this period. The 60-day simulation reproduces the chlorophyll $a$ levels $\left(>1 \mu \mathrm{gl}^{-1}\right.$ ) estimated for the bloom on day 42 from SeaWiFS, and indicates maximum consumption of nutrients and $\mathrm{CO}_{2}$ after our departure from the SOIREE site. Hannon et al. also investigated the sensitivity of bloom development to changes in the initial conditions (such as shallower and deeper mixed layers) and in the iron fertilisation strategy (pulsed versus single enrichments). Such sensitivity analysis will likely prove invaluable in designing future iron enrichment experiments. The main datasets from SOIREE are available on the accompanying CD-ROM.

\subsection{The fate of the SOIREE bloom-export versus subduction}

The second tenet of the Iron Hypothesis (Martin, 1990) focuses on the fate of iron-elevated algal stocks. Both downward particulate export (Martin, 1990) and the subduction of surface waters where phytoplankton have accumulated (Cooper et al., 1996) have been put forward as plausible 
outcomes to iron enrichment. Nodder and Waite (2001), Charette and Buesseler (2001), and Trull and Armand (2001) report on the relationship between iron enrichment and subsequent downward export fluxes. All three studies conclude that export was not enhanced during the 13-day occupation of the SOIREE site. Moreover, Hannon et al. (2001) did not observe any evidence of a mass sedimentation event in 60-day model simulations of the SOIREE. They conducted a sensitivity analysis of how iron supply might influence aggregation rates and alter algal sinking rates, and reported that increased stickiness of cells (due to nutrient stress) did result in higher downward export fluxes in further model simulations. Trull et al. (2001) investigate the likelihood of the subduction of surface waters with iron-elevated algal stocks, and conclude that the long-term sequestration of carbon in these waters is unlikely.

\subsection{The geological past and the present day}

The results of in situ mesoscale iron experiments have implications for both paleo-oceanography and large-scale iron-enrichments of the Southern Ocean (Sarmiento and Orr, 1991). Watson et al. (2000) use the main findings of SOIREE in a modelling simulation of the magnitude and timing of shifts in dust (iron) and atmospheric carbon dioxide levels during the glacial-interglacial terminations. They concluded that elevated iron supply during the glacial maxima could account for up to $50 \%$ of the observed decrease in atmospheric carbon dioxide at this time. The potential to extrapolate the results from SOIREE to other seasons, or other regions is discussed by Boyd et al. (2000) and Trull et al. (2001). The outcome of large-scale fertilisation of the Southern Ocean remains unknown since no iron-elevated downward fluxes of biogenic particulates were observed, and the potential for long-term sequestration of carbon via subduction seems unlikely. Law and Ling (2001) in their study of nitrous oxide, comment on the long-term implications of increased iron availability on emissions of the greenhouse gas, nitrous oxide. They update previous estimates (Fuhrman and Capone, 1991) to suggest that the increased nitrous oxide flux may largely cancel out the negative feedback from increasing sequestration of carbon.

\subsection{The nature and design of in situ mesoscale iron fertilisation experiments}

The SOIREE study also provided detailed information on the important role of the physical oceanographic regime at the study site on the outcome of the experiment. Abraham et al. (2000) presented a model of the physical evolution of the iron-enriched patch of water based on observations during the 13-day site occupation - during which the area of the $\mathrm{SF}_{6}$ labelled waters increased four-fold - and after 42-days (based on estimates of the areal size of the patch from SeaWiFS). The increase in size of the patch had important implications for the transfer of chemical and biological stocks between the surrounding HNLC waters and the patch. Bowie et al. (2001) identified that horizontal dispersion was a significant loss term for the added iron to the patch, while Abraham et al. (2000) reported that the largest algal loss term for the SOIREE bloom was not sedimentation or herbivory, but horizontal dispersion. Furthermore, such an exchange of waters (see Fig. 2) represents a departure from natural fertilisation events (DiTullio and Laws, 1991), which will mainly occur over greater length scales (see satellite images in Boyd et al., 1998).

In the case of SOIREE, the bloom has been likened to a chemostat where silicic acid is entrained from outside of the patch, and the bloom-species (large diatoms) are 'washed out' (Boyd et al., 2000; 


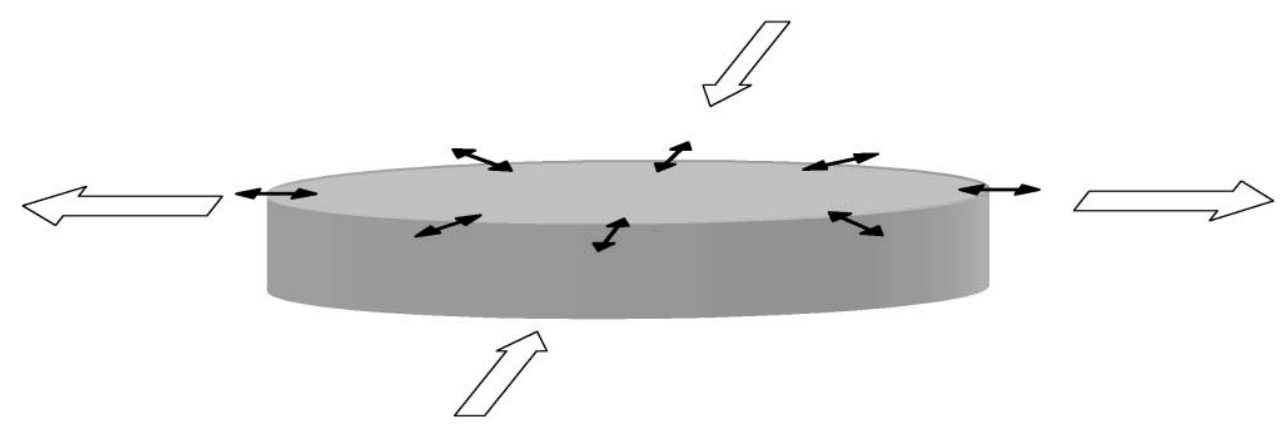

Fig. 2. A schematic of the putative SOIREE 'chemostat' - the exchange between the iron-fertilised waters of the SOIREE patch and the surrounding HNLC waters during the experiment. Solid black arrows denote diffusion of water to and from the water masses at the periphery of the patch, while the large open arrows represent the effect of strain in the horizontal currents stretching the patch. The area of the fertilised patch increased from 50 to $\sim 250 \mathrm{~km}^{2}$ by day 13 , and was $>1000 \mathrm{~km}^{2}$ by day 40 (see Abraham et al. (2000) for more details). Figure courtesy of Edward Abraham.

see Fig. 2 in present study). The diffusion of water to and from the water masses at the periphery of the patch is responsible for the mixing of phytoplankton cells and iron out of the patch, and the mixing of HNLC waters (low iron, high silicic acid, and low chlorophyll $a$ with few diatoms) into the patch. The effect of strain in the horizontal currents stretching the patch alters its shape, but does not by itself alter the concentrations of properties within the patch. Diffusion tends to broaden the patch width, while stretching tends to make it thinner (for more details see Abraham et al., 2000). Such dispersion of chlorophyll $a$ and diatoms will tend to reduce the effects of algal self-shading (Mitchell et al., 1991) and may prevent the attainment of $C_{\mathrm{r}-}$ the critical threshold of particle abundances required to initiate the coagulation of phytoplankton cells (Jackson, 1990). Observed particle abundances for the algal community during SOIREE were $<C_{\mathrm{r}}$ (Waite and Nodder, 2001).

This enhancement of the macronutrient inventory of the bloom and/or such sustained algal losses may delay the timing of the decline of the bloom. Thus, these artefacts may confound interpretation of the bloom status - the progression from onset to stationary phase leading to the initiation of mass sedimentation, as is observed in other regions such as the NE Atlantic (see Newton et al., 1994). SOIREE provides strong evidence of the important role of physics in determining the outcome of the experiment, and suggests this should be considered in the design of future experiments to ensure that the fate of the bloom is monitored. It may not be simply a case of increasing the length-scale of fertilisation since, in addition to the logistical difficulties of mapping/constraining a patch of larger area, the physical regime may impose a significantly different physical evolution of $\mathrm{SF}_{6}$ labelled waters and thus modify the expression of the biogeochemical responses to iron enrichment.

\subsection{Conclusions and future work}

In summary, we list the most significant results from the SOIREE study, and suggest several themes for future research. The main findings are as follows:

(i) Confirmation of iron limitation of phytoplankton growth rate at this site in summer, and the likelihood that these results are widely applicable to polar waters in spring and summer. 
(ii) Modelling studies indicate that the observed shifts in the algal carbon:silicic acid uptake ratio, and the large drawdown of carbon dioxide during SOIREE have important implications for setting the magnitude of decreases in atmospheric carbon dioxide levels during the last glacial maximum (see Watson et al., 2000).

(iii) Iron-mediated decreases in $\mathrm{pCO}_{2}$ and concurrent increases in DMS levels during SOIREE are trends that under conditions of climate change (such as increased aridity - see Falkowski et al., 1998) may both represent negative feedbacks with respect to global warming. These changes in the levels of climate-reactive gases appear to be mediated by different algal groups - diatoms $\left(\mathrm{pCO}_{2}\right)$ and haptophytes $\left(\mathrm{DMSP}_{\mathrm{p}}\right)$. In contrast, it is possible that longer-term changes in nitrous oxide may represent a positive feedback.

(iv) The greatest algal loss term during SOIREE was due to dispersion of cells from the fertilised waters. The physical oceanographic conditions at this and future study sites will play a major role in determining the resulting biological signal.

(v) The longevity of the SOIREE bloom ( $>40$ days) appears to be related to the persistently elevated iron levels observed after day $11 / 12$. The iron was mainly present as $\mathrm{Fe}^{\mathrm{II}}$, and the concentration of iron-binding ligands increased towards the end of the SOIREE site occupation. The entrainment of the surrounding silicic acid-rich waters into the iron-fertilised patch (the SOIREE 'chemostat' - see Fig. 2) also may have contributed to the bloom longevity.

(vi) The absence of any significant downward particulate export, of the accumulated phytoplankton via a mass sedimentation event, can be inferred from modelling studies, and is suggested by SeaWiFS satellite images (note, caveats regarding the accuracy of SeaWiFS algorithms apply). It is possible that the onset of a mass algal sedimentation event may have been prevented by the horizontal dispersion of high chlorophyll $a$ waters within the patch to the surrounding HNLC waters (see Fig. 2).

The papers in this volume put forward recommendations for future studies in Southern Ocean waters including:

(i) Investigation of mesoscale iron-enrichments in HNLC waters characterised by low ambient silicic acid concentrations, or in polar waters dominated by non-siliceous bloom-forming species such as Phaeocystis.

(ii) A detailed study of the mechanism(s) responsible for the increase in iron-binding ligands (and $\mathrm{Fe}^{\mathrm{II}}$ concentrations) towards the end of SOIREE.

(iii) Alteration of the design of mesoscale iron release experiments to overcome the potential artefacts due to mixing between iron-fertilised waters with the surrounding HNLC waters.

(iv) To assess the timescales in polar waters for the onset of a mass algal sedimentation event, subsequent to the accumulation of iron-elevated algal stocks.

(v) Investigation of longer term positive feedback responses to iron fertilisation.

\section{References}

Abraham, E.R., Law, C.S., Boyd, P.W., Lavender, S.J., Maldonado, M.T., Bowie, A.R., 2000. Importance of stirring in the development of an iron-fertilized plankton bloom. Nature 407, 727-729.

Abraham, E.R., (in preparation). Stirring controls the development of the SOIREE bloom, unpublished manuscript. 
Bakker, D.C.E., Watson, A.J., Law, C.S., 2001. Southern Ocean iron enrichment promotes inorganic carbon drawdown. Deep-Sea Research II 48, 2483-2507.

Banse, K., 1990. Does iron really limit phytoplankton production in the offshore subarctic Pacific. Limnology and Oceanography $35,772-775$.

Banse, K., 1991. Iron availability, nitrate uptake and exportable new production in the subarctic Pacific. Journal of Geophysical Research 96, 741-748.

Bidigare, R.R., Hanson, K.L., Buesseler, K.O., Wakeham, S.G., Freeman, K.H., Pancost, R.D., Millero, F.J., Steinberg, P., Popp, B.N., Latasa, M., Landry, M.R., Laws, E.A., 1999. Iron-stimulated changes in ${ }^{13}$ C fractionation and export by equatorial Pacific phytoplankton: toward a paleogrowth rate proxy. Paleoceanography 14, 589-595.

Bowie, A.R., Maldonado, M.T., Frew, R.D., Croot, P.L., Achterberg, E.P., Mantoura, R.F.C., Worsfold, P.J., Law, C.S., Boyd, P.W., 2001. The fate of added iron during a mesoscale fertilisation experiment in the polar Southern Ocean. Deep-Sea Research II 48, 2681-2701.

Boyd, P.W., Abraham, E.R., 2001. Iron-mediated changes in phytoplankton photosynthetic competence during SOIREE. Deep-Sea Research II 48, 2529-2550.

Boyd, P.W., LaRoche, J., Gall, M., Frew, R., McKay, R.M.L., 1999. The role of iron, light and silicate in controlling algal biomass in sub-Antarctic waters SE of New Zealand. Journal of Geophysical Research 104, 13395-13408.

Boyd, P.W., Watson, A.J., Law, C.S., Abraham, E.R., Trull, T., Murdoch, R., Bakker, D.C.E., Bowie, A.R., Buesseler, K.O., Chang, H., Charette, M., Croot, P., Downing, K., Frew, R., Gall, M., Hadfield, M., Hall, J., Harvey, M., Jameson, G., La Roche, J., Liddicoat, M., Ling, R., Maldonado, M.T., McKay, R.M., Nodder, S., Pickmere, S., Pridmore, R., Rintoul, S., Safi, K., Sutton, P., Strzepek, R., Tanneberger, K., Turner, S., Waite, A., Zeldis, J., 2000. A mesoscale phytoplankton bloom in the polar Southern Ocean stimulated by iron fertilization. Nature 407, 695-702.

Boyd, P.W., Wong, C.S., Merrill, J., Whitney, F., Snow, J., Harrison, P.J., Gower, J., 1998. Atmospheric iron supply and enhanced vertical carbon flux in the NE subarctic Pacific - is there a connection? Global Biogeochemical Cycles 12, 429-441.

Cavender-Bares, K.K., Mann, E.L., Chisholm, S.W., Ondrusek, M.E., Bidigare, R.R., 1999. Differential response of equatorial Pacific phytoplankton to iron fertilization. Limnology and Oceanography 44, 237-246.

Charette, M.A., Buesseler, K.O., 2000. Does iron fertilisation lead to rapid carbon export in the Southern Ocean? Geochemistry, Geophysics, Geosystems no. 2000GC000069.

Coale, K.H., et al., 1996. A massive phytoplankton bloom induced by ecosystem-scale iron fertilization experiment in the equatorial Pacific Ocean. Nature 383, 495-501.

Comiso, J.C., McClain, C.R., Sullivan, C.W., Ryan, J.P., Leonard, C.L., 1993. Coastal zone color scanner pigment concentrations in the Southern Ocean and relationships to geophysical surface features. Journal of Geophysical Research 98, 2419-2451.

Cooper, D.J., Watson, A.J., Nightingale, P.D., 1996. Large decrease in ocean-surface $\mathrm{CO}_{2}$ fugacity in response to in situ iron fertilisation. Nature 383, 511-513.

Croot, P.L., Bowie, A.R., Frew, R.D., Maldonado, M.T., McKay, M., LaRoche, J., Boyd, P.W., 2001. Persistence of dissolved iron and $\mathrm{Fe}^{\mathrm{II}}$ in an iron induced phytoplankton bloom in the Southern Ocean. Geophysical Research Letters, submitted.

de Baar, H.J.W., 1994. von Liebig's law of the minimum and plankton ecology (1899-1991). Progress in Oceanography 33, 347-386.

de Baar, H.J.W., Boyd, P.W., 1999. The role of iron in plankton ecology and carbon dioxide transfer of the global oceans. In: Hanson, R.B., Ducklow, H.W., Field, J.G. (Eds.), The Dynamic Ocean Carbon Cycle: A Midterm Synthesis of the Joint Global Ocean Flux Study, International Geosphere Biosphere Programme Book Series. Cambridge University Press, Cambridge, pp. 61-140 (Chapter 4).

de Baar, H.J.W., Buma, A.G.J., Jacques, G., Nolting, R.F., Trequer, P.J., 1989. Trace metals—-Iron and manganese effects on phytoplankton growth. Berichte zur Polarforschung 65, 34-44.

de Baar, H.J.W., et al., 1995. Importance of iron for plankton blooms and carbon dioxide drawdown in the Southern Ocean. Nature 373, 412-415.

de Baar, H.J.W., et al., 1999. Low dissolved Fe and the absence of diatom blooms in remote Pacific waters of the Southern Ocean. Marine Chemistry 66, 1-34. 
DiTullio, G.R., Laws, E.A., 1991. Impact of an atmospheric-oceanic disturbance on phytoplankton community dynamics in the North Pacific Central Gyre. Deep-Sea Research 38, 1305-1329.

Falkowski, P.G., Barber, R.T., Smetacek, V., 1998. Biogeochemical controls and feedbacks on ocean primary production. Science 281, 200-206.

Frew, R., Bowie, A., Croot, P., Pickmere, S., 2001. Macronutrients and trace-metal geochemistry of an in situ ironinduced Southern Ocean bloom. Deep-Sea Research II 48, 2467-2481.

Frost, B.W., 1996. Phytoplankton blooms on iron rations. Nature 383, 475-476.

Fuhrman, J.A., Capone, D.G., 1991. Possible biogeochemical consequences of ocean fertilisation. Limnology and Oceanography 68, 1951-1959.

Gall, M.P., Boyd, P.W., Hall, J., Safi, K.A., Chang, H., 2001a. Phytoplankton processes. Part 1: Community structure during the Southern Ocean Iron RElease Experiment (SOIREE). Deep-Sea Research II 48, 2551-2570.

Gall, M.P., Strezpek, R., Maldonado, M., Boyd, P.W., 2001b. Phytoplankton processes. Part 2: Rates of primary production and factors controlling algal growth during the Southern Ocean Iron RElease Experiment (SOIREE). Deep-Sea Research II 48, 2571-2590.

Gran, H.H., 1931. On the conditions for the production of plankton in the sea, Rapports et proces verbaux des Reunions. Conseil International pour l'exploration de la Mer 75, 37-46.

Hall, J., Safi, K., 2001. The impact of in situ Fe fertilisation on the microbial food web in the Southern Ocean. Deep-Sea Research II 48, 2591-2613.

Hannon, E., Boyd, P.W., Silvoso, M., Lancelot, C., 2001. Modeling the bloom evolution and carbon flows during SOIREE: Implications for future in situ iron-enrichments in the Southern Ocean. Deep-Sea Research II 48, 2745-2773.

Hart, T.J., 1934. On the phytoplankton of the Southwest Atlantic and the Bellingshausen Sea 1929-1931. Discovery Reports 8, 1-268.

Jackson, G.A., 1990. A model of the formation of marine algal flocs by physical coagulation processes. Deep-Sea Research 37, 1197-1211.

Lancelot, C., Hannon, E., Becquevort, S., Veth, C., de Baar, H.J.W., 2000. Modeling phytoplankton blooms and related carbon export production in the Southern Ocean: application to the Atlantic sector in austral spring 1992. Deep-Sea Research I 47, 1621-1662.

Landry, M.R., Constantinou, J., Latasa, M., Brown, S.L., Bidigare, R.R., Ondrusek, M.E., 2001. The biological response to iron fertilization in the eastern equatorial Pacific (IronEx II). III. Dynamics of phytoplankton growth and zooplankton grazing. Marine Ecology Progress Series 201, 57-72.

Law, C.S., et al., (in preparation). Vertical mixing during the SOIREE experiment and biogeochemical implications, unpublished manuscript.

Law, C.S., Ling, R., 2001. Nitrous oxide flux and response to increased iron availability in the Antarctic Circumpolar Current. Deep-Sea Research II 48, 2509-2527.

Law, C.S., Watson, A.J., Liddicoat, M.I., Stanton, T., 1998. Sulphur hexafluoride as a tracer of biogeochemical and physical processes in an open-ocean iron fertilisation experiment. Deep-Sea Research II 45, 977-994.

Maldonado, M.T., Boyd, P.W., LaRoche, J., Strzepek, R., Waite, A., Bowie, A.R., Croot, P.L., Frew, R.D., Price, N.M., 2001. Iron uptake and physiological response of phytoplankton during a mesoscale Southern Ocean iron experiment. Limnology and Oceanography, in press.

Martin, J.H., 1990. Glacial-interglacial $\mathrm{CO}_{2}$ change: the iron hypothesis. Paleoceanogaphy 5, 1-13.

Martin, J.H., Fitzwater, S.E., Gordon, R.M., 1991. We still say iron deficiency limits phytoplankton growth in the subarctic Pacific. Journal of Geophysical Research 96 (20), 699-700.

Martin, J.H., Gordon, R.M., Fitzwater, S.E., 1990. Iron in Antarctic waters. Nature 345, 156-158.

Martin, J.H., et al., 1994. Testing the iron hypothesis in ecosystems of the equatorial Pacific Ocean. Nature 371, 123-129.

Mitchell, B.G., Brody, E.A., Holm-Hansen, O., McClain, C., Bishop, J., 1991. Light limitation of phytoplankton biomass and macronutrient utilization in the Southern Ocean. Limnology and Oceanography 36, 1662-1677.

Moore, J.K., Abbott, M.R., Richman, J.G., Smith, W.O., Cowles, T.J., Coale, K.H., Gardner, W.D., Barber, R.T., 1999. SeaWiFS satellite ocean color data from the Southern Ocean. Geophysical Research Letters 26, $1465-1468$. 
Newton, P.P., Lampitt, R.S., Jickells, T.D., King, P., Boutle, C., 1994. Temporal and mesoscale variability of biogenic particle fluxes in the context of the JGOFS north-east Atlantic process studies at 47N 20W (1989-1990). Deep-Sea Research I 41, 1617-1642.

Nodder, S.D., Waite, A.M., 2001. Is Southern Ocean organic carbon and biogenic silica export enhanced by ironstimulated increases in biological production? Sediment trap results from SOIREE. Deep-Sea Research II 48, 2681-2701.

Peng, T.-H., Broecker, W.S., 1991. Factors limiting the reduction of atmospheric $\mathrm{CO}_{2}$ by iron fertilisation. Limnology and Oceanography 36, 1919-1927.

Sarmiento, J.L., Orr, J.C., 1991. Three-dimensional simulations of the impact of Southern Ocean nutrient depletion on atmospheric $\mathrm{CO}_{2}$ and ocean chemistry. Limnology and Oceanography 36, 1928-1950.

Sunda, W.G., Huntsman, S.A., 1997. Interrelated influence of iron, light and cell size on marine phytoplankton growth. Nature 390, 389-392.

Takeda, S., 1998. Influence of iron availability on nutrient consumption ratio of diatoms in oceanic waters. Nature 393, 774-777.

Trull, T., Armand, L., 2001. Insights into Southern Ocean carbon export from the $\delta^{13} \mathrm{C}$ of particles and dissolved inorganic carbon during the SOIREE iron experiment. Deep-Sea Research II 48, 2655-2680.

Trull, T., Rintoul, S.R., Hadfield, M., Abraham, E.R., 2001. Circulation and seasonal evolution of polar waters south of Australia: Implications for iron fertilization of the Southern Ocean. Deep-Sea Research II 48, 2439-2466.

Turner, S., Harvey, M., Gall, M., Safi, K., Hall, J., Law, C.S., Boyd, P.W., 2001. Enhanced dimethyl sulphide production from in situ iron enrichment in Antarctic waters. Science, in preparation.

Waite, A.M., Nodder, S.D., 2001. The effect of in situ iron addition on the sinking rates and export flux of Southern Ocean diatoms. Deep-Sea Research II 48, 2635-2654.

Watson, A.J., Bakker, D.C.E., Ridgwell, A.J., Boyd, P.W., Law, C.S., 2000. Effect of iron supply on Southern Ocean $\mathrm{CO}_{2}$ uptake and implications for glacial atmospheric $\mathrm{CO}_{2}$. Nature 407, 730-733.

Watson, A.J., Law, C.S., Van Scoy, K.A., Millero, F.J., Yao, W., Friederich, G.E., Liddicoat, M.I., Wanninkhof, R.H., Barber, R.T., Coale, K.H., 1994. Minimal effect of iron fertilization on sea surface carbon dioxide concentrations. Nature 371, 143-145.

Watson, A.J., Liss, P.S., Duce, R.A., 1991. Design of a small-scale iron fertilisation experiment. Limnology and Oceanography 36, 1960-1965.

Zeldis, J., 2001. Mesozooplankton community composition, feeding, and export production during SOIREE. Deep-Sea Research II 48, 2615-2634.

Zentara, S.J., Kamykowski, D., 1981. Geographic variation in the relationship between silicic acid and nitrate in the South Pacific Ocean. Deep-Sea Research 28A, 455-465. 